\title{
Koszorúér-angioplasztika súlyos miokardiális infarktusban a légzés és a keringés eszközös támogatásával
}

\author{
Voith László, Nowotta Fanni, Skoda Réka, Merkely Béla, Becker Dávid
}

Semmelweis Egyetem, Városmajori Szív- és Érgyógyászati Klinika, Budapest

Levelezési cím:

Dr. Voith László, 1125 Budapest Diós árok 35/A. E-mail: laszlo.voith@gmail.com

Célkitűzés: Akut miokardiális infarktusos, a primer perkután koronáriaintervenció ( $\mathrm{pPCl}$ ) során a légzés és/vagy a keringés eszközös támogatását, illetve hipotermiát igénylö páciensek betegségének klinikai lefolyásának elemzése.

Betegek és módszerek: 2016. 01. 01. és 12. 31. között 1435 betegben végeztünk akut miokardiális infarktusban primer koszorúér-intervenciót (543 ST-elevációs - STEMI - és 892 nem ST-elevációs - NSTEMI). Közülük 158 eset (a betegek 11,0\%a, 95 férfi és 63 nő) reanimált, illetve korábban már infarktuson átesett vagy egyéb szívizom-károsodás miatt keringési elégtelenségben, kardiogén sokkban, esetleg az akut miokardiális infarktus (AMI) mellett egyéb súlyos betegségben is szenvedett. Ezen betegeknél a perkután koronáriaintervenció $(\mathrm{PCl})$ mellett egyéb eszközös segítségre is szükség volt. $A$ beavatkozás alatt és után intermittáló pozitív nyomású lélegeztetés (IPPB) 93, intraaortikus ballonpumpa (IABP) 22, IPPB + IABP 23, IPPB és/vagy IABP + hipotermia 13, IPPB és/vagy IABP + extracorporalis membrán oxigenátort (ECMO-t) 7 esetben alkalmaztuk. Az egyenáramú (DC) sokkot és/vagy pacemakerkezelést igénylő malignus ritmuszavarokat külön nem elemeztük. Vizsgáltuk a panasz kezdetétől az első EKG-ig, illetve a ballonnyitásig eltelt időt.

Eredmények: A STEMI esetek között az eszközös támogatást igénylő betegek aránya magasabb volt, mint a NSTEMI-csoportban (95 beteg 17,5\% vs. 63 beteg 7,2\%). A panaszok kezdetétől az első egészségügyi kontaktusig (EKG-készítés), mind kórházi felvételtől a reperfúzióig (a koszorúér-tágító ballon nyitásáig) eltelt idő hosszabb volt az összes beteg átlagánál. 30 napon belül 63 (39,9\%), egy éven belül újabb 38 (24,0\%) beteget vesztettünk, $57(36,1 \%)$ beteg egy éven túl életben volt.

Megbeszélés: Véleményünk szerint a primer PCl-t súlyos állapotú AMI-s betegekben a fenti módszerek segítségével meg kell kísérelni akkor is, ha azok a még elfogadhatónak tekintett 12 órán túl kerülnek kórházi felvételre. Nincsenek olyan ismereteink, amikkel az akut infarktusos beteg felvételekor már eldönthető lenne a beavatkozás késői kimenetele.

Kulcsszavak: akut miokardiális infarktus, primer koronáriaintervenció, gépi lélegeztetés, intraaortikus ballonpumpa, extracorporalis membránoxigenátor

Coronary angioplasty in serious myocardial infarction with device suppported respiration and circulation

Aim of the study: To analyze of clinical course of pts. with acute myocardial infarction requiring respiratory and/or circulatory device help or hypothermia during primary coronary intervention.

Patients and methods: From 01. 01. 2016 to 31. 12. 2016 we performed 1435 primary percutaneous coronary intervention in 543 acute ST elevation (STEMI) and 892 non-ST elevation (NSTEMI) myocardial infarction. 158 cases (11.0\% of patients, 95 male and 63 female) were unconscious after reanimation, having heart failure or being in cardiogenic shock caused by previous infarction or another kind of heart disease, or suffering from other severe disease beside AMI. These patients needed special device support in addition to PPCI, during and after the procedure, intermittent positive pressure breathing (IPPB) 93, intraaortic balloon pump (IABP) 22, IPPB + IABP 23, IPPB and/or IABP + hypothermia 13, IPPB and/or IABP + AV extracorporeal membrane oxygenator (ECMO) 7 in cases. Malignant rhythm disorders requiring direct-current (DC) shock and/or pacemaker treatment have not been separately studied. We analyzed the time intervals from onset of complaint to first ECG and to balloon inflation.

Results: Among STEMI pts the proportion of required special device support was higher than in the NSTEMI group (95 pts. $17.5 \%$ vs. 63 pts. $7.2 \%$ ). Both the time from the beginning of the complaints to the first medical contact (ECG) and to the hospital and the reperfusion (complaint-balloon opening) was longer than average. Within 30 days 63 (39.9\%) pts were lost, another $38(24.0 \%)$ by the end of first year. 57 (36.1\%) pts. survived more than 1 year.

Discussion: In our opinion, primary PCI should be attempted using the above-mentioned methods in AMI pts in serious condition even if the patients are admitted to the hospital over the 12 hours, which is considered acceptable. We do not have the knowledge to predict the late outcome of the intervention by the time of the admission of an AMI patient.

Keywords: acute myocardial infarction, primary coronary intervention, mechanical ventilation, extracorporeal membrane oxygenator

A kézirat 2020. 02. 18-án érkezett a szerkesztőségbe, 2020. 04. 15-én került elfogadásra. 
Az akut szívizominfarktus kezelésének két alapvető célja a beteg életben tartása és a szívizomelhalás mértékének csökkentése. Az életben tartásra több lehetőség van: az ingerképzési és vezetési zavarok kivédése defibrillátorral és pacemakerrel, az oxigénnek a szövetekhez eljuttatását javító légzés- és keringéstámogatással (gépi lélegeztetés [IPPB], intraaortikus ballonpumpa [IABP], arteriovenosus membránoxigenátor [AV ECMO], vagy egyéb, a bal kamra működését segítő eszköz [LVAD]), reanimált betegeknél az agyi anyagcsere hipotermiával történő lassítása és az agyszövet reperfúziós károsodása elleni védelem is. A szívizomkárosodás mérséklése, az elzáródott ér áramlásának rekanalizálással történő helyreállítása az utóbbi másfél évtizedben csaknem kizárólag primer perkután koronáriaintervencióval ( $\mathrm{pPCl}$ ) történik, az esetek döntő részében stentbeültetéssel. Fontos a beavatkozás alatt a megfelelő antikoaguláns- és trombocitaaggregációgátló-kezelés, ezt az intervenció után is folytatni kell.

\section{Betegek és módszerek}

A klinikánkon 2016. január 1. és december 31. között 1435 betegben 543 ST-elevációs (STEMI) és 892 nem ST-elevációs (NSTEMI) miokardiális infarktus miatt végzett $\mathrm{pPCl}$ közül 158 betegben (95 férfi és 63 nő, az összes betegek $11,0 \%$-a) volt szükség a légzés/keringés eszközös támogatására, illetve hipotermia alkalmazására (1. és 2. táblázat).

Az adatok az Egyetem Medsol rendszerében és a Nemzeti Szívinfarktus Regiszterben általunk rögzítettek voltak. A kort és a nemet a részletes elemzés során nem vettük figyelembe. Külön tüntettük fel az összes beteg kórelőzményében szereplő jelentős alapbetegségeket (3. táblázat).

A kórelőzményi adatok mellett vizsgáltuk a panasz kezdetétől az első egészségügyi kontaktusig (EKG-készítés: P-Eü), az intervenciós központba felvételre kerülésig $(F-B)$ és a felvételtől a ballonnyitásig terjedő időszak hosszát (F-B). Elemeztük az intervenció kivitelezésének részleteit. A DC-sokkot és/vagy pacemakerkezelést igénylő malignus ritmuszavarokat külön nem vizsgáltuk. Két esetben került sor akut koszorúérmütétre.

\section{Eredmények}

A 2016. 01. 01. - 12. 31. között STEMI miatt végzett 1435 pPCl-s beteg kórelőzményében számos már lezajlott vagy folyamatos kezelést igénylő betegség szerepel (3. táblázat).

Az akut infarktus miatt felvett, légzés- és/vagy keringéstámogatást igénylő betegeinknél számos olyan krónikus vagy akut betegség, illetve állapot volt a 3. táblázatban felsoroltak mellett - a betegek egy részénél
1. TÁBLÁZAT. A betegek száma, kora, a nemek az infarktus típusa szerinti megoszlása, és a súlyos, a légzés/keringés eszközös támogatását igénylő betegek intézetünkben 2016. 01. 01 - 12. 31 között

\begin{tabular}{|l|c|l|l|l|l|}
\hline & Betegek & Kor (év) & Férfi & Nő & \multicolumn{1}{|c|}{ Súlyos } \\
\hline STEMI & 543 & $65,1 \pm 13,2$ & 364 & 179 & $95(14,7 \%)$ \\
\hline NSTEMI & 892 & $69,7 \pm 11,2$ & 579 & 313 & $63(7,1 \%)$ \\
\hline Összes & 1435 & $68,0 \pm 12,1$ & 943 & 492 & $158(11,0 \%)$ \\
\hline
\end{tabular}

2. TÁBLÁZAT. A légzés/keringéstámogatást igénylő betegek kora, a beavatkozások módja

\begin{tabular}{l|l} 
Betegek & 158
\end{tabular}

\begin{tabular}{|l|l|}
\hline Átlagéletkor (év) & $69,1 \pm 15,9$ \\
\hline IPPB & 93 \\
\hline IABP & 22 \\
\hline IPPB+IABP & 23 \\
\hline IPPB/IABP+H & 13 \\
\hline IPPB/IABP+AV ECMO & 7 \\
\hline
\end{tabular}

IPPB = intermittáló pozitív túlnyomásos lélegeztetés, IABP = intraaortikus ballonpumpa, $\mathrm{H}=$ hipotermia, $\mathrm{AV}$ ECMO = arteriovenózus extracorporalis membránoxigenizátor

kombinációban - amelyek az infarktus miatt kialakult állapotot súlyosbították és a kezelést nehezítették (1. ábra). Az eszközösen támogatott betegeknél a szükséges légzés/keringés támogatás aránya a STEMI csoportban magasabb volt az NSTEMI-hez viszonyítva (2. ábra).

Mivel az NSTEMI-s betegeknél a panaszok kezdete nem volt mindig definiálható, esetleg hosszú időt töltöttek más kórházban a koronáriaintervenció előtt, a panaszok kezdetétől az intervencióig eltelt időt a STEMI-csoportban hasonlítottuk össze (3. táblázat). 543 beteg közül 487-ben (432 eszközösen nem segített és 55 esz-

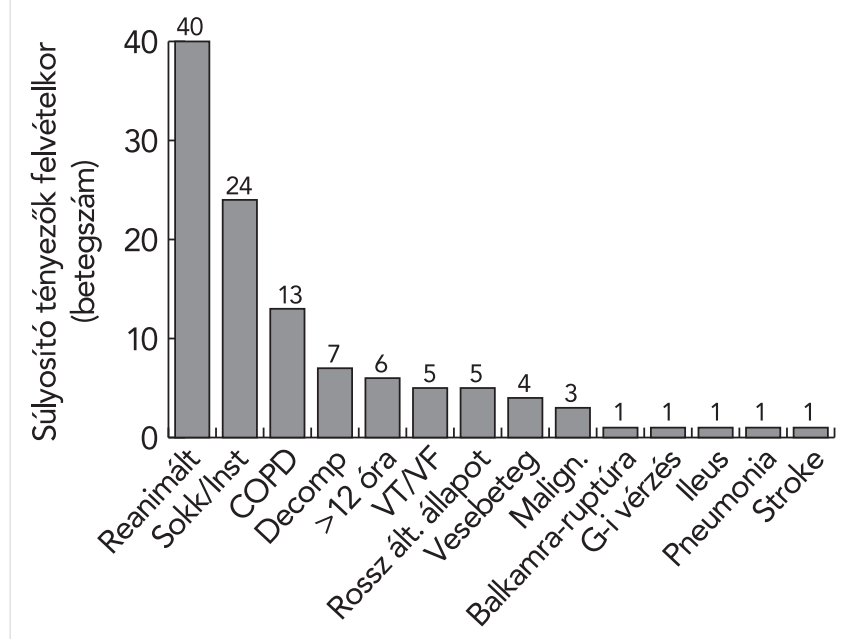

1. ÁBRA. A 158 légzés- és/vagy keringéstámogatást igénylő betegek között 112 súlyosító tényező volt diagnosztizálható felvételkor, néhány betegnél kombinációban 


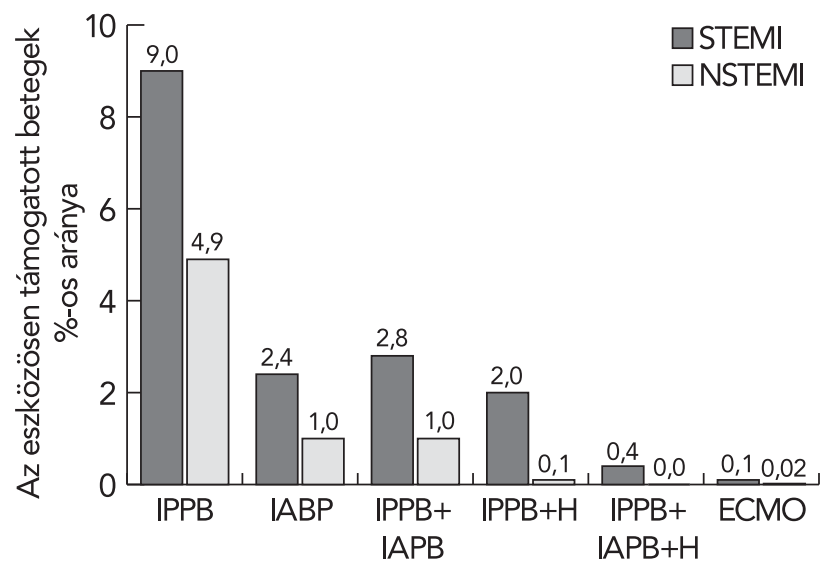

2. ÁBRA. A légzés- és/vagy keringéstámogatást igénylők százalékos aránya beavatkozási típusok szerint a pPCl-re került betegek számához viszonyítva $(n=158)$

közösen segített) betegnél tudtuk az időintervallumok részleteit értékelni (4. táblázat).

Az eszközös támogatást nem igénylő betegeknél a panasz kezdete és az első EKG között eltelt idő átlaga hosszabb volt a súlyos betegekéhez képest, ugyanakkor a panasztól, illetve a kórházi felvételtől a ballonnyitásig eltelt idő rövidebb. Ez utóbbit magyarázza a gépi lélegeztetés, illetve az eszközös keringéstámogatás megkezdésének időigénye.

Az eszközösen támogatott PPCl-s betegek közül 30 napon belül 63 (39,9\%), egy éven belül még $38(24,0 \%)$ beteget vesztettünk, 57 (36,1\%) beteg volt életben egy éven túl (5. táblázat).

A 6. táblázatban feltüntettük a légzés/keringés segítését nem igénylő betegeink halálozási arányait. Egyéves intervallumban a STEMI és NSTEMI között statisztikailag értékelhető különbség nincs.

\begin{tabular}{|c|c|c|c|}
\hline $\begin{array}{l}\text { Összes STEMI } \\
(n=487)\end{array}$ & $\begin{array}{l}\text { Súlyos nélkül } \\
(\mathrm{n}=432)\end{array}$ & $\begin{array}{l}\text { Súlyos } \\
(n=55)\end{array}$ & \\
\hline $\begin{array}{l}\text { Panasz - } \\
\text { első EKG átlag }\end{array}$ & 5 óra 54 perc & 5 óra 02 perc & $p=0,04$ \\
\hline $\begin{array}{l}\text { Felvétel - } \\
\text { ballonnyitás átlag }\end{array}$ & 54 perc & 1 óra 9 perc & $p=0,02$ \\
\hline $\begin{array}{l}\text { Panasz - } \\
\text { ballonnyitás átlag }\end{array}$ & 10 óra 32 perc & $\begin{array}{l}13 \text { óra } 55 \\
\text { perc }\end{array}$ & $p=0,002$ \\
\hline
\end{tabular}

6. TÁBLÁZAT. A eszközös támogatást nem igénylő betegeink halálozás aránya 2016-ban

<30 napos halálozás 1 éves halálozás

\begin{tabular}{lcc|}
\hline STEMI & 10 & 27 \\
$\mathrm{n}=448$ & $2,2 \%$ & $6,0 \%$ \\
\hline NSTEMI & 6 & 57 \\
$\mathrm{n}=829$ & $0,7 \%$ & $6,9 \%$ \\
\hline
\end{tabular}

\section{Megbeszélés}

Miokardiális infarktusban számos prediktív tényező határozza meg az állapot súlyosságát és későbbi kimenetelét, függ az életkortól, a szívizom korábbi állapotától, az elzáródott ér ellátási területétől, a társbetegségektől, a szövődményektől (ingerképzési-vezetési zavarok, keringési elégtelenség, kardiogén sokk következményes szervelégtelenséggel stb.), ezek mellett jelentős mértékben a panasz kezdete és az ér rekanalizációja között eltelt időtől is (1).

A kezelés során elsődleges cél az oxigénnek a szövetekhez eljutása. A légzés és a keringés javítása érdekében szükség esetén eszközös támogatást kell igénybe venni: gépi lélegeztetés, intraaortikus ballonpumpa, extracorporalis membránoxigenátor,

3. TÁBLÁZAT. A 1435 pPCl-s beteg főbb kórelőzményi adatai, az abszolút értékek alatt zárójelben a \%-os arány

\begin{tabular}{|l|c|c|c|c|c|c|c|c|c|c|}
\hline & Hipert. & DM & Perif. & MI & Decomp & Stroke & PCI & ACBG & Rean. \\
\hline $\begin{array}{l}\text { STEMI } \\
\text { n=543 }\end{array}$ & $490(89,6)$ & $153(30,0)$ & $43(7,9)$ & $162(29,6)$ & $40(7,3)$ & $29(27,8)$ & $160(29,3)$ & $17(3,1)$ & $41(7,5)$ \\
\hline $\begin{array}{l}\text { NSTEMI } \\
n=892\end{array}$ & $802(85,2)$ & $403(42,8)$ & $189(20,1)$ & $418(44,4)$ & $146(15,5)$ & $76(8,1)$ & $443(47,1)$ & $78(8,3)$ & $11(1,7)$ \\
\hline
\end{tabular}

$\mathrm{n}=892$

Hipert. = hipertónia, $\mathrm{DM}=$ diabetes mellitus, Perif. = perifériás érbetegség, Decomp $=$ keringési elégtelenség, Stroke $=$ lezajlott agyi vaszkuláris történés, PCI = perkután koronáriaintervenció, $\mathrm{ACBG}=$ aorta-coronaria bypass graft mütét

5. TÁBLÁZAT. A légzés és keringés eszközös támogatását igénylő betegek 30 napos és egy éven belül halálozása, valamint az egy évet túlélök aránya

\begin{tabular}{|l|l|l|l|l|l|c|c|c|} 
& & IPPB & IABP & IPPB/IABP & $\begin{array}{c}\text { IPPB/IABP } \\
+ \text { IPPB/IABP }\end{array}$ & $\begin{array}{c}\text { Összes } \\
+ \text { ECMO }\end{array}$ \\
\hline Halálozás <30 nap & STEMI & 23 & 3 & 9 & 4 & 4 & 43 & 63 \\
& NSTEMI & 17 & 1 & 2 & 0 & 1 & 20 & $39,9 \%$ \\
\hline \multirow{2}{*}{ Halálozás 31-365 nap } & STEMI & 13 & 2 & 3 & 3 & 1 & 22 & 38 \\
& NSTEMI & 12 & 2 & 2 & 0 & 0 & 16 & $24,0 \%$ \\
\hline \multirow{2}{*}{ Egyéves túlélés } & STEMI & 13 & 8 & 2 & 6 & 1 & 31 & 57 \\
\hline
\end{tabular}


esetleg egyéb, a bal kamra működését segítő eszköz (LVAD).

Ha a beteg hipoventilál (centrális vagy perifériás ok miatt a légzés frekvenciája jelentősen megváltozik és/ vagy mélysége csökken), vagy légúti akadályozottság (asthma bronchiale, krónikus obstruktív légúti betegség stb.) miatt a gázcsere nem kielégítő, a vér $\mathrm{pO}_{2}$-szint csökkenését a belélegeztetett oxigén nem tudja megakadályozni, intermittáló pozitív túlnyomásos lélegeztetésre van szükség $(2,3)$.

Ezeknek a betegeknek a gépi lélegeztetése nagy körültekintést igényel. A spontán légzéshez képest megfordul a levegő beáramlási ciklusa. Az intrathoracalis nyomás növekedésekor csökken a vénás beáramlás, csökken a bal kamra telődése, ennek következtében a perctérfogat is. A betegek pulmonalis vaszkuláris rezisztenciája megnőhet, ez szintén csökkenti a bal kamra telődését és a perctérfogatot $(4,5)$.

A keringés romlása miatt bekövetkező kardiogén sokkban segít a régóta alkalmazott, relatíve egyszerüen behelyezhető intraaortikus ballonpumpa. Ennek az eszköznek a használata emeli a tenziót, javítja a koszorúér-keringést, azonban nem növeli a perctérfogatot, és nem csökkenti a nekrotikus terület nagyságát $(6,7,8)$. Keringési okból kritikus állapotú infarktusos betegeknél jelentős támogatás lehet az extracorporalis membránoxigenátor alkalmazása. Ez a keringéstámogató eszköz arteriovenosus extracorporalis szívmotor, aminek artériás és vénás szára éren keresztül bevezethető, emeli a perctérfogatot, és statisztikailag növeli a túlélés valószínüségét $(9,10)$.

A bal kamrai eszközök (LVAD) behelyezése bonyolult, és az áruk magas. Bár vannak biztató klinikai vizsgálatok, használatuk jelenleg a gyakorlatban még nem terjedt el.

A hirtelen szívhalál miatt reanimált esetekben régóta végeznek sürgős koronarográfiát, szükség esetén ilyenkor $\mathrm{PCl}$ is történik, aminek klinikai eredményeit az agyi anyagcsere lassítása és a reperfúziós károsodás csökkentése miatt végzett mérsékelt hipotermia alkalmazása javítja $(11,12)$.

AMI-ban a primer perkután koronária-angioplasztika jelenleg csaknem kizárólagosan alkalmazott rekanalizációs eljárás, az intravénás trombolitikus kezelésnél gyorsabban ér el eredményt, az infarktusért felelőssé tehető (culprit) lézióban nem marad vissza reziduális szűkület, és kisebb a szisztémás vérzés veszélye $(13,14,15)$.

Betegeink közül az összes, egy év alatt miokardiális infarktussal felvett és pPCl-re került esetek 11\%-ában került sor respirátor és/vagy intraaortikus ballonpumpa, 7 esetben ECMO alkalmazására is. A 40, reanimálás után felvett betegnél 13 esetben alkalmaztunk hipotermiát a $\mathrm{pPCl}-\mathrm{k}$ elvégzésekor.

Az IPPB-, IABP- és hipotermiaarányunk a Nemzeti Szívinfarktus Regiszterben található tárgyévi országos adatoknál kissé magasabb volt. AV ECMO-ra vonatkozó hazai adatokat nem találtunk.
A szívizomsejtek elhalása az infarktusért felelős koszorúér culprit („tettes”) szűkületének elzáródásától számítva időarányosan nő $(16,17)$, fontos hogy a beteg minél rövidebb idő alatt olyan intézetbe kerüljön, ahol a fent részletezett, a légzést és keringést támogató eljárások lehetősége és alkalmazásukban gyakorlattal rendelkező személyzet rendelkezésre állnak. Ezek a szempontok máig nem vesztették el a jelentőségüket, a legutóbbi ajánlásokban is szerepelnek (18, 19, 20).

Ebben a kérdésben a jelen hazai gyakorlat nem kedvező. Az infarktussal felvett betegek magas komorbiditási aránya mellett egy részük a mellkasi fájdalom kezdetét követően már jelentős késéssel fordul orvoshoz, nem mindig kerül primeren intervenciós központba, és itt a megajánlott intervencióba való beleegyezés előtt néha jelentős késést okozva hezitál. 2016-ban az általunk felvett STEMI-s betegeknél a mellkasi fájdalomtól a reperfúzióig eltelő idő átlagosan több mint 10 óra, a medián érték 5 óra volt. A jelen közleményben analizált 55, eszközösen segített STEMI-s betegünknél ennél is hosszabb átlagos időt találtunk, ami többszöröse a szívizom megtartásának patofiziológiai szempontból kívánatos első két „arany” óránál és a mortalitást csökkentő első 3 óránál, amelyek a betegek későbbi sorsát meghatározzák. A betegek felvételétől a ballonnyitásig eltelő idő megegyezik a hazai és nemzetközi gyakorlattal.

A légzést és keringést támogató eszközök alkalmazása jelentős segítség lehet a túlélésben, de minden alkalommal meg kell vizsgálni a várható komplikáció és nyereség arányát, elsősorban az ECMO alkalmazásának tervezésekor (21).

A légzés/keringés eszközösen segített, magas rizikójú primer $\mathrm{PCl}$-s betegeink közül 30 napon belül az esetek közel 40\%-át, egy éven belül további $24,0 \%$-át vesztettük el, a betegek valamivel több, mint egyharmada volt életben egy éven túl. A halál 2 esetben extrakardiális ok (malignus tumor) miatt következett be.

30 napos túlélési adataink egyeznek az irodalomban találhatóakkal (22), vegyes (STEMI-NSTEMI) anyagunkkal összevethető, egyéves túlélésre vonatkozó adatot nem találtunk.

A fent részletezett súlyosságú betegekben történő pPCI magas rizikójú, az egy éven túl életben levő betegek arányát figyelembe véve a rendelkezésre álló eszközökkel mégis meg kell kísérelni a rekanalizációt.

Az elmúlt években több kockázati pontszámot (risc score) dolgoztak ki koronáriabetegek, ezen belül akut koronáriaszindrómások kezelésére vonatkozóan (ismertebbek: GRACE, PURSUIT, TIMI, EMMACE, C-ACS, ProACS, DAPT). Ezek számszerű eredményei valószínűsítik az adott betegnél végzendő beavatkozás rizikóját, de nem adnak olyan konkrét információkat, amikkel egy adott akut miokardiális infarktusos beteg felvételekor eldönthető lenne a későbbi kimenetel. 


\section{Nyilatkozat}

A szerzök kijelentik, hogy az eredeti közlemény megírásával kapcsolatban nem áll fenn velük szemben pénzügyi vagy egyéb lényeges összeütközés, összeférhetetlenségi ok, amelyek befolyásolhatják a közleményben bemutatott eredményeket, az abból levont következtetéseket vagy azok értelmezését.

\section{Irodalom}

1. Acharya B. Predictors of outcomes in myocardial infarction and cardiogenic shock Cardiology in Review 2018; 26: 255-266. doi: 10.1097/CRD.0000000000000190

2. Bach JR. Mechanical insufflation/exsufflation: has it come of age? A commentary. Eur Respir J 2003; 21: 385-386. doi: 10.1183/09031936.03.00098702

3. Winck JC, Goncalves MR, Lourenco C, et al. Effects of mechanical insufflation-exsufflation on respiratory parameters for patients with chronic airway secretion encumbrance. Chest 2004; 126: 774780. doi: 10.1378/chest.126.3.774

4. Fessler HE. Heart-Lung interaction: applications in the critically ill. Eur Resp J 1997; 10: 226-237. doi: 10.1183/09031936.97.10010226 5. Hurford WE. Cardiopulmonary interactions during mechanical ventilation. Int Anesthesiol Clin 1999; 37: 35-46.

6. Sjauw KD, Engstrom AE, Vis MM, et al. A systematic review and metaanalysis of intra-aortic balloon pump therapy in ST-elevation myocardial infarction: should we change the guidelines? Eur Heart J 2009; 30: 459-468. doi: 10.1093/eurheartj/ehn602. Epub 2009 Jan 23.

7. Patel MR, Smalling RW, Thiele $\mathrm{H}$, et al. Intra-aortic balloon counter pulsation and infarct size in patients with acute anterior myocardial infarction without shock: the CRISP AMI randomized trial. JAMA 2011; 306: 1329-1337. doi:10.1001/jama.2011.1280

8. Thiele H, Zeymer U, Neumann FJ, et al. IABP- SHOCK II Trial Investigators. Intraaortic balloon support for myocardial infarction with cardiogenic shock. N Engl J Med 2012; 367: 1287-1296. doi: 10.1056/NEJMoa1208410

9. Esper AS, Bermudez C, Dueweke EJ, et al. Extracorporeal membrane oxygenation support in acute coronary syndromes complicated by cardiogenic shock. Cath Cardiovasc Intervent 2015; 86(S1): S34-S54. doi: 10.1002/ccd.25871. Epub 2015 Feb 25.

10. Pabst $D$, Foy A, Peterson B, et al. Predicting survival in patients treated with extracorporeal membrane oxygenation after myocardial infarction. Critical Care Medicine 2018; 46. e359-e363. doi: 10.1097/CCM.0000000000002995.
11. Spaulding CM, Joly LM, Rosenberg A, Monchi M, Weber SN Dhainaut JF, et al. Immediate coronary angiography in survivors of out-of hospital cardiac arrest. N Engl J Med 1997; 336: 1629-633. doi: 10.1056/NEJM199706053362302

12. Crisholm GE, Greais A, Thim T, et al. Safety of therapeutic hypothermia combined with primary percutaneous coronary intervention after out-of-hospital cardiac arrest. Eur Heart J Acute Cardiovasc Care 2015; 4: 60-63. doi: 10.1177/2048872614540093

13. Keeley EC, Boura JA, Grines CL. Primary angioplasty versus intravenous thrombolytic therapy for acute myocardial infarction: a quantitative review of 23 randomised trials. Lancet 2003; 361: 13 20. DOI: 10.1016/S0140-6736(03)12113-7

14. Boersma E. Primary coronary angioplasty vs. thrombolysis Group. Does time matter? A pooled analysis of randomized clinica trials comparing primary percutaneous coronary intervention and in-hospital fibrinolysis in acute myocardial infarction patients. Eur Heart J 2006; 27: 779-788. DOI: 10.1093/eurheartj/ehi810

15. Jánosi $A$, Ofner $P$, Merkely $B$, et al. Szívinfarctus miatt kezelt betegek korai és késői prognózisa. Orv Hetil 2013; 154: 1297-1302. doi: 10.1556/OH.2013.29679

16. Boersma E, Maas ACP, Deckers JW, et al. Early thrombolytic treatment in acute myocardial infarction: reappraisal of the golden hour. Lancet 1996; 348: 771-775. doi: 10.1016/S01406736(96)02514-7

17. Gersh BJ, Antman EM. Selection of the optimal reperfusion strategy for STEMI: does time matter? Eur Heart J 2006; 27: 761-763. doi:10.1093/eurheartj/ehi775

18. The Task Force of the European Society of Cardiology (ESC) 2017 ESC Guidelines for the management of acute myocardial infarction in patients presenting with ST-segment elevation. Eur Heart J 2018; 39: 119-177. doi: 10.1093/eurheartj/ehx393.

19. 2017 AHA/ACC Clinical Performance and Quality Measures for Adults With ST-Elevation and Non-ST-Elevation Myocardial Infarction A Report of the American College of Cardiology/American Heart Association Task Force on Performance Measures JACC 2017; 70: 2048-2090. doi: 10.1016/j.jacc.2017.06.032.

20. Becker D, Merkely B. Akut coronaria szindróma ellátása - 2016. Orv Hetil 2016; 157: 1500-1506. doi: 10.1556/650.2016.30574 21. Cheng R, Hachamovitch R, Kittleson M, et al Complications of extracorporeal membrane oxygenation for treatment of cardiogenic shock and cardiac arrest: a meta-analysis of 1,866 adult patients. Ann Thorac Surg 2014; 97: 610-616. doi: 10.1016/j.athoracsur.2013.09.008.

22. Parhar K, Millar V, Zochios V, et al. Clinical outcomes of patients undergoing primary percutaneous coronary intervention for acute myocardial infarction requiring the intensive care unit. J Intensive Care 2018; 6: 5. doi: 10.1186/s40560-018-0275-y. 